\title{
Olga Drobot
}

(C) Drobot O., 2017

State Higher Educational Establishment «Pereyaslav-Khmelnytsky State Pedagogical University named after Hryhoriy Skovoroda»

\section{DEVELOPMENT OF PROFESSIONAL CONSCIOUSNESS FROM THE VIEWPOINT OF PREPARATION OF FUTURE SPECIALISTS}

Development of professional consciousness of the future specialist is examined via formation of the specialist's own system of transforming information and explaining the reality, where his subjective world is transformed, in the course of professional training and practice, into the world of profession of a practicing specialist. Today's preparation of future specialists must be aimed more at systemic development of their professional consciousness. Certain professional consciousness development methods have been outlined.

Keywords: development of professional consciousness, professional semantics, psychosemantic methods, professional training, university-based preparation

\section{Introduction}

According to the logic of development of complex systems, patterns of development of the professional's consciousness must concur with the patterns of development of professional consciousness per se [9], especially in the light of university-based preparation of specialists.

An individual's activity-based indirect relationships with a group (in every age category, an individual is included to a new social group which becomes the reference group for him) influence development of his personality [1;7]. Therefore, consciousness becomes dependent not so much from the activity as such as from the leading activity.

The most intensive processes of the specialist's development occur at the time of study in a higher education institution; however, development of professional consciousness continues during the person's entire professional ontogenesis.

The world of profession consists of specific (for every profession) accents of perception and reflection of the world by persons for whom profession became a way of life. The world of profession manifests itself via professional semantics, professional reflection of situations, professional social perception and professional aspects of communication. Professional 


\section{Psychological and pedagogical problems of modern specialist formation}

activity is conducted on the basis of certain professional and personal experience. Gaining this experience requires development of a system of professional meanings and mastering new cognitive schemes, development of special forms of thinking, partial transformation of semantic structures, which on the whole, compose the image of the world typical for this particular activity.

The structure of professional consciousness was described in the provisions formulated by E. F. Zeyr [4] for personality-oriented professional education. The author shows that development of a specialist envisages development of: axiological orientation and professional consciousness; social and professional intellect; emotional-volitional sphere; positive attitude toward the world and oneself; independence, autonomy and confidence in oneself; professionally important qualities and auto-competence.

In today's world, more attention should be devoted to cognitionoriented education, intellectual development of graduates and their preparation for the future socio-professional life. A person starts professional labor activity with the already-developed, value-based consciousness, knowing what interests he would like to realize with his work.

Professional environment forces a person to transform his valuebased orientations, forming a practical consciousness plan influenced by personality's value-based orientations and particular circumstances of professional work life. For instance, O. I. Hrynchuk [2] uses materials of an empirical study to show the role of value-based orientations in development of professional self-perception of future managers.

Continuing this line of thought, the scholar D. V. Ronzin writes that content-wise, level-wise and structural specifics of professional consciousness determine forecasting, goal setting, planning, decision making, control, evaluation and correction of the specialist's activity [8].

\section{Materials and methods}

Goals of academic programs are insufficient to develop all structural components of professional consciousness. The study of professional consciousness as a subject of psychological research is developing in psychosemantic direction, and requires use of psychosemantic methods. The science of psychosemantics is a branch of psychology studying genesis, composition and functioning of the individual system of meanings and personality-related senses in the person's consciousness. Psychosemantic research paradigm is the most capable of recording deep manifestations of human subjectivity, i. e. psychosemantic one. Psychosemantics propose a study of categorical structures of individual consciousness and composition of meaning-based models of certain types of professional consciousness, 
filled with concrete content [3]. Study of a certain type of professional consciousness means reconstruction of the system of individual meanings and senses of every future specialist or professional and of the entire professional group. Determination of common psychosemantic content in professional consciousness, through which one perceives objects, oneself and others, is what differentiates one type of professional consciousness from another in its psychosemantic representation.

Contemporary psychological science uses a number of methods for quality development of professional consciousness in future professionals. U. L. Morokhovska [6] has devised and implemented a program of developing new professional senses, and proved its applicability for development of motivational components of professional self-determination in students. O. V. Drobot's methodology of Managerial Decision Making Situations (MDMS) [3] outlines sophistication and development levels of administrative consciousness in future managers. O. M. Lozova's technicalsemantic methodology, Sense Formation Initiation Technique [5], creates conditions for initiation of production by respondents of linguistic texts to overcome predetermination of old senses and accomplish the rethinking task.

\section{Results}

The conclusion that university-based preparation must be aimed at systemic development of professional consciousness in the future specialist remains of contemporary importance.

\section{References}

1. Akopov, G. V. (2004). Obrazovanie i razvitie soznaniya [Education and development of consciousness]. Problemy soznaniya $v$ rossiyskoy psihologii - Problem of consciousness in Russian psychology (pp. 161-175). Moscow: MPSI; Voronezh: NPO «MODEK». (in Russian)

2. Grinchuk, O. I. (2006). Tsinnisni orientatsiyi yak pokaznik profesiynoyi samosvidomosti maybutnih menedzheriv [The valued orientations as index of professional consciousness of future managers]. In L. E. Orban-Lembrik (Ed.), Zbirnik naukovikh prac': filosofiia, sociologiia, psikhologiia - Collection of scientific works: philosophy, sociology, psychology (11 (1) pp. 56-65). Ivano-Frankivsk: VDV CIT. (in Ukrainian)

3. Drobot, O. V. (2016). Profesiyna svidomist kerivnika [Professional consciousness of leader]. Kyiv: Talkom. (in Ukrainian)

4. Zeyr, E. F. (2006). Psihologiya professiy [Psychology of professions]. Moscow: Akademicheskiy proekt. (in Russian)

5. Lozova, O. M. (2009). Teoretichni pidstavi ta praktika zastosuvannya tehniki initsiyuvannya smisloutvorennya [Theoretical 


\section{Psychological and pedagogical problems of modern specialist formation}

grounds and practice of applying the technique of initiating the meaning of formation]. In S. D. Maksimenko (Ed.), Aktualni problemy psihologiyi Actual problems of psychology (9 (4) ed., pp. 249-256). Kyiv: Institut psikhologii imeni G. S. Kostiuka NAPN Ukraini. (in Ukrainian)

6. Morokhovska, U. L. (2011). Rozvitok motivatsiynih skladovih profesiynogo samoviznachennya maybutnih psihologiv [Development of motivational components of professional self-determination of future psychologists] (Candidate's thesis, Derzhavnij vishchij navchal'nij zaklad «Universitet menedzhmentu osviti», Kyiv, Ukraine). (in Ukrainian)

7. Petrovskiy, A. V. (1984). Problema razvitiya lichnosti s pozitsii sotsialnoy psihologii [The problem of personality development from the standpoint of social psychology]. Voprosy psihologii - Questions of psychology, 4, 13-17. (in Russian)

8. Ronzin, D. V. (1991). Professionalnoe soznanie uchitelya kak nauchno-prakticheskaya problema [Professional consciousness of teacher as a scientific and practical problem]. Psihologicheskiy zhurnal Psychological Journal, 5, 65-72 (in Russian)

9. Hanina, I. B., \& Leont'ev, D. A. (Eds.). (2011). Psihologiya subektivnoy semantiki: Istoki i razvitie [Psychology of subjective semantics: Origins and development]. Moscow: Smysl. (in Russian)

\section{Ольга Дробот. Становлення професійної свідомості $з$ точки зору підготовки майбутніх фахівців.}

Розглядається становлення професійної свідомості майбутнього фахівия через формування у нього власної системи перетворення інформації та пояснення дійсності, де його суб'єктивний світ, у процесі професійного навчання та практики перетворюється за змістом до світу професії прачюючого фахівия. Сучасна підготовка майбутнього фахівия повинна спрямовуватись більще на системне формування його професійної свідомості. Наводяться методи формування професійної свідомості.

Ключові слова: становлення професійної свідомості, професійна семантика, психосемантичні методи, професійне навчання, вузівська підготовка.

\section{Olga Drobot. Ksztaltowanie świadomości zawodowej pod kątem przygotowania przyszłych fachowców.}

Analiza ksztaltowania świadomości zawodowej przyszlego fachowca poprzez tworzenie u niego wlasnego systemu przetwarzania informacji $i$ wyjaśnienie rzeczywistości, w której jego subiektywny świat $w$ trakcie nauki $i$ praktyki zawodowej zmienia się pod względem spojrzenia na świat pracujacego zawodowo fachowca. Wspótczesne przygotowanie przyszlego fachowca powinno być przede wszystkim ukierunkowane na systemowe 
ksztaltowanie jego świadomości zawodowej. W artykule podane zostaty metody owego ksztattowania świadomości zawodowej.

Slowa kluczowe: ksztaltowanie świadomości zawodowej, semantyka zawodowa, metody psychosemantyczne, studia zawodowe, przygotowanie na uczelni wyższej.

Received 16.06.2017

\section{Information about the author:}

Drobot Olga - Doctor of Psychological Sciences, Professor at the Department of Psychology, State Higher Educational Establishment «Pereyaslav-Khmelnytsky State Pedagogical University named after Hryhoriy Skovoroda». 